\title{
The Limits of Territorial Interest Representation in the European Union
}

Anna-Lena Högenauer (Maastricht University) ${ }^{1}$

\begin{abstract}
According to the literature on lobbying, actors gain access to European policymaking in return for information and expertise. It is often assumed that territorial actors will be in a position to provide such information by virtue of being the implementing authorities. By contrast, this article argues that there is a need to examine further to what extent regions are able to use channels of interest representation and to supply information, what kind of channels they use and how they frame their message. For this purpose, it examines the strategies of seven legislative regions in two concrete policy cases. In particular, it argues that the seven regions rely predominantly on mediated channels of interest representation as their capacity and willingness to use unmediated channels of interest representation is limited. Secondly, it argues that regions tend to use technical language over politicized language in lobbying to avoid overt conflict, especially with national governments or other regions from the member state, but that their ability to produce extensive (technical) expertise is also very limited.
\end{abstract}

\footnotetext{
${ }^{1}$ Dr. Anna-Lena Högenauer is currently postdoctoral researcher at Maastricht University for the Observatory of Parliaments after Lisbon (OPAL) project (464-10-074). This article is based on previous research conducted while at the University of Edinburgh.
} 


\section{Introduction}

Since the 1980s, regional governments have become increasingly aware of the impact of European integration and more assertive in European Union (EU) policymaking. On the one hand, this is reflected in the evolution of domestic procedures for coordination in EU affairs in the case of federal and strongly regionalized states. On the other, their level of activism in Brussels - the location of the main EU institution (the European Commission (hereafter 'the Commission', the European Parliament, hereafter 'the Parliament', the Council of Ministers and the European Council) - has increased. ${ }^{\mathrm{i}}$ After the establishment of the first Brussels offices of regions in the 1980s, the number of sub-national representations has grown to 219 (GREENWOOD, 2011, p. 439). Two thirds of those represent individual subnational governments (MARKS et al., 2002). In addition, regional lobbying has led to the establishment of new forms of involvement such as the consultative Committee of the Regions and greater access to the Council of Minister. The Commission's 2001 White Paper on Governance and the increased use of consultations has also opened opportunities for territorial interest representation (KNODT et al., 2011, p. 350).

The strong presence of regions in Brussels raises a number of questions as to the strategies of interest representation of these regions. On the one hand, regional governments tend to define themselves as institutions of representative democracy that represent legitimate general interests rather than as 'lobbyists', which is a term that can evoke narrower economic or societal interests. On the other hand, they 'can and do become 'lobbyists' for their own distinct interests as public authorities', especially where the costs of implementation or financial benefits are at stake 
(GREENWOOD, 2011, p. 438). Thus, regional governments benefit from an informational asymmetry on the European level where understaffed decision-makers - especially in the Commission and European Parliament - are willing to grant access to policy-making in return for information (CHALMERS, 2013, p. 39; QUITTKAT and KOTZIAN, 2011, p. 403). The challenge for regional authorities is to establish their credibility and gain attention (PRINCEN 2011, p. 931).

According to the idea that there is a situation of information asymmetry in the European Union, European policy-makers, and especially the Commission, need expertise and political support for policy-formulation. However, demand for information and the willingness and ability to supply information are two different issues (KNODT et al., 2011, p. 355; CHALMERS, 2013, p. 40). Not all regional governments may have the same capacity to use the same range of channels and provide the same types of information (GREENWOOD, 2011, p. 440). Thus, in order to shed light on the capacity of regions to engage in EU policy-making, this article will investigate two questions: The first is about the tactics of regions and the second about the type of information that is supplied. Firstly, to what extent do regions use instruments of access that are unmediated by national governments, such as interregional networks, direct contacts with the European institutions and the organization of events (cf. MARKS, 1993; JEFFERY, 2000), as compared to access mediated by national governments? Secondly, to what extent do regional governments use their position as implementers of European policies to provide technical information, and to what extent do they use their position as elected institutions to make openly politicised claims (cf. CHALMERS, 2013)? The focus lies thus not so much on the causes of the strategies (cf. HÖGENAUER, 2013), but 
on the nature of the strategies of interest representation, i.e. the tools and arguments that regions make use of.

In order to answer these questions, the article will focus on seven legislative regions, Scotland, Bavaria, Mecklenburg-West Pomerania, Flanders, Wallonia, Vorarlberg and Carinthia, i.e. cases from the strongest group of regions from a constitutional perspective. These regions may not be representative of the whole spectrum of regions, but they represent a 'best case' scenario for a study focusing on the capacity of regions to become active in EU policy-making. They have implementation and legislative competences in the policy area under investigation and have thus a high degree of legitimacy, an experienced administration, the grass-root knowledge that the Commission needs and a motivation to mobilize (e.g. to preserve their competences). In general, these regions should thus be able to develop and implement particularly ambitious and resource-intensive strategies especially compared weaker regions. These cases thus allow us to see how far regional interest representation can go. At the same time, they represent different levels of economic prosperity and population size, which creates variation in their level of resources and their precise capacity to mobilize (cf. HÖGENAUER, 2013).

The policy cases are two environmental Directives (the Bathing Water and the Flood Risk Management Directive), which are regulatory policies and thus representative of the bulk of EU policy-making. The Bathing Water Directive provides a new framework for assessing the quality of water in lakes and at the coast in relation to health risks for bathers. The Flood Risk Management Directive provides the first European-wide regulation of flood risk management strategies including flood maps, plans for responses to flooding and the planning of flood barriers or flood plains. ${ }^{\text {ii }}$ 
All seven regions were affected by the policy problem (salience). In the case of the Flood Risk Management Directive, all regions were affected by severe flooding in the years preceding the directive and suffered from extensive material damage and in extreme cases - human losses. In the case of the Bathing Water Directive, all seven regions contain a substantial number of official bathing waters and thus had to consider the implementation costs of a stricter policy. Most of the regions also had to take into account the potential negative impact on public opinion of bathing waters suddenly being classified as unhealthy, whereas Carinthia with its exceptionally good water quality saw an opportunity to tighten the competition.

In addition, all seven regions have implementation competences in the policy areas, and all regions except for the Austrian Länder have also legislative competences. The Bathing Water Directive was replacing an existing outdated Directive, but the Flood Risk Management Directive represented a first incursion of the EU into that policy area.

Finally, all seven regions were active in the domestic coordination of the national position on these policy cases (mediated access), which further demonstrates that all of the regions are, in principle, interested in influencing the policy outcome. This makes the policies also good cases to study the willingness and ability of regions to mobilize in Brussels.

From a methodological point of view, the case studies are reconstructed from qualitative data - 36 interviews with officials from all seven regions, their Brussels offices, national ministries and European institutions and ten shorter oral or written exchanges with officials. A full list of interviews is included in the appendix. In addition, speeches, newsletters, press releases and position papers were analyzed 
where those were available. This methodology supports the aim of the article to analyze the nature of the strategies of interest representation of the regions, as it provides insights not only into the channels that were used, but also into how those channels were used across the whole policy cycle from drafting to implementation (i.e. variation across policy stages) and how the regions framed their message (i.e. technocratic or politicized).

In terms of structure, the article will first discuss the literature on territorial interest representation and, in particular, the channels of mediated and unmediated access available to the regions in general. The second section will then analyse the findings on the strategies of the regions in the concrete policy cases and analyse them along the lines of the core questions: the extent of the strategies, the choice of tactics (mediated/unmediated) and the politicization of the message. The third section will discuss the implications of these findings for a number of discussions in the literature on multi-level governance and territorial interest representation. Finally, it will conclude by summarizing the core argument that the capacity of regions to engage in extensive lobbying strategies on the European level and to supply certain kinds of information is extremely limited.

\section{The Opportunities for Territorial Interest Representation in a multi-level European Union}

\section{Multi-level Venue Shopping}

The multi-level governance (MLG) literature argues that the EU is 'a system of continuous negotiation among nested governments at several territorial tiers supranational, national, regional and local - as the result of a broad process of 
institutional creation and decisional reallocation that has pulled some previously centralised functions of the state up to the supranational level and some down to the local/regional level' (MARKS, 1993, p. 392). Supranational actors, in particular the Commission, are assumed to engage in alliances with the subnational level that allow both levels to circumvent central governments and strengthens their position in the decision-making process (MARKS et al., 1996; HOOGHE and MARKS, 2001). However, with regard to regions, the enthusiasm of the mid-1990s soon ebbed and was replaced by the recognition that central governments were still the strongest actors and that they may also remain the main point of contact for regions (cf. JEFFERY, 2000; HOOGHE and MARKS, 2001).

The literature on interest organizations and multi-level venue shopping, which also draws on a broader application of the MLG literature, asks to what extent the reallocation of competences to the European level has led to a reorientation of strategies of interest representation to the European level, which actors are the target of European strategies and which factors influence such strategies (MARKS et al., 1996; BEYERS, 2002; BEYERS et al., 2008). Both literatures face the question how national access impacts European level strategies: Are actors that have good access to national policy-makers more or less likely to mobilize at the European level?

There is broad agreement in the MLG literature that constitutional strength has a positive impact on the likelihood of mobilization of a region (MARKS et al., 1996; NIELSEN and SALK, 1998; MARKS et al., 2002; DONAS and BEYERS, 2012). Most authors from the literature on multi-level venue-shopping similarly conclude that organizations that are strong domestically are also more likely to develop strong European strategies, as they tend to have better access to information and possible access to European actors via their national networks (BEYERS, 2002; GREER et 
al., 2008, p. 427; BEYERS and KERREMANS, 2012). By contrast, TATHAM (2010) suggests that regions with a greater number of competences are less likely to engage in conflictual strategies in Brussels and more likely to cooperate with their central governments. The apparent contradiction may be resolved if one takes into account that not every instance of unmediated access expresses conflict with the national government. With regard to our case study regions, this means that we should expect extensive mobilization at the European level, in line with the strong domestic position of the regions.

At the same time, the literature on interest groups also confirms JEFFERY's claim that legislative regions regard domestic channels as their primary contact point (2000): BEYERS and KERREMANS show that the interest groups of four member states establish first their national network, before creating a European level strategy (2012, pp. 283-4).

The literature on lobbying also offers further distinctions between strategies, in particular outsider and insider tactics. Outside tactics (or 'seeking voice') are oriented towards the public and include the organization of independent meetings or of media strategies, compared to insider tactics ('seeking access') oriented at the policy-making elites, such as participation in consultations, expert meetings and the use of emails and phone calls to European actors (cf. BEYERS, 2004; 2008, p. 1189). According to WOLL, EU lobbying mostly involves insider tactics, especially consultation, and a cautious and constructive approach (2006, p. 463). However, whether an interest group focuses more on one or the other strategy depends to some extent on the organization and resources of the group, e.g. whether they can offer expertise or mobilize people. CHALMERS (2013, pp. 43, 52-4) suggests that the use of multiple tactics works best, as it demonstrates commitment to a position. Most 
groups do indeed use both strategies simultaneously, but diffuse interests, tend to use outside tactics more and tend to get more access to the EP than to the Commission, whereas specific interests associated with insider tactics tend to have more access to the Commission (BOUWEN, 2004; EISING, 2007; DÜR and MATEO, 2013; CHALMERS, 2013: 49).

The case study regions could in principle use both strategies: As legislative regions with competences in the policy area they possess a high degree of legitimacy that could support a strategy based on politicized claims and 'voice'. At the same time, as implementing authorities, they possess expertise that could support insider tactics. It This can again be linked to TATHAMS's finding that constitutionally strong regions are less likely to engage in conflictual strategies in Brussels (2010). Regions can in principle become active in Brussels even in the absence of conflict within the member state. Even if there is conflict, they might not choose an openly conflictual strategy, but rather argue on the technical level. At the same time, regions may face a trade off between the two tactics as both tactics represent resource-challenges: the organization of an outsider strategy with independent events requires organizational resources, where as an effective insider strategy requires expertise.

Thus, both literatures raise questions as to the extent to which legislative regions really use Brussels strategies and, in particular, unmediated access to the European level. In addition, in order to assess to what extent the strategies of the regions are conflictual, it is important to also analyze how the message is framed and whether conflict is emphasized or deemphasized by a certain region.

While the primary concern of the article is to analyse the nature of the strategies of interest representation, differences in strategy are to be expected and need to be 
explained. Much of the multi-level governance literature (esp. by Marks and Hooghe) relies on implicit or explicit rationalist assumptions, for example about how regions reorient their strategies after governments transfer competences to the European level, or on the reasons why governments transfer competences. Similarly, rationalist assumptions influence part of the Europeanization literature, in the form of the argument that 'misfit' between the European policies and the national policies generates costs and hence pressures for adaptation (cf. BACHE, 2008, HERITIER, 1996). This article also follows the rational choice institutionalist assumptions that actors will weigh the costs and benefits of the issue at stake and of the available courses of action within a given institutional framework (cf. HALL and TAYLOR, 1996; PETERS, 2000). With regard to the matter at hand, two hypotheses can be derived.

Firstly, among the available options, regions will choose the least costly strategy to achieve their goals. As argued below, this will normally be mediated access where the national government takes the lead in the representation of a joint interest. Unmediated access, and even more so an outside tactic oriented towards the public, will mostly be used when disagreements with the national government make mediated access less effective (cf. HÖGENAUER, 2013). Secondly, regional governments will only opt for outside tactics in case their primary concerns are political rather than technical in nature. As outside tactics are resource-intensive, it is to be expected that they will only be used for issues that are seen to be particularly salient. In addition, outside tactics that rely on a strong political message and unmediated access tend to place the position of an individual region (or group of regions) above the interest of the state as a whole, and thus increase the likelihood of friction (or open conflict) with the national government. 
At first glance, the regulatory nature of the directives might suggest that the arguments at stake in the two policy cases are primarily technical: about definitions of water quality, the type of flood risk management required etc. In line with the rationalist assumptions, these arguments would favour an insider strategy that focuses on information exchange and persuasion, rather than a resource-intensive outsider strategy focusing on voice. The media and public would probably show limited interest in complex scientific arguments. However, this assessment neglects underlying potential for political conflict. In both cases, the precise technical agreements could result in considerable implementation costs for the regions and could thus raise the question of proportionality and what a policy goal is 'worth'. In addition, the Flood Risk Management Directive is a European intervention in a policy area hitherto regulated on the regional (and in Austria national) level. It thus limits the legislative margin of manoeuvre of the regions and raises the question of subsidiarity. In line with the hypotheses, we would thus expect outsider strategies to be more likely to occur on the Floor Risk Management Directive than on the Bathing Water Directive, especially in conjunction with political arguments about subsidiarity. As the issues at stake can thus be defined in different ways, the preferences of each region have been defined subjectively, as expressed in interviews and documents.

Of course, in order to understand the strategies of regions on the European level, one first needs to understand the options available to regions. The next two sections will therefore briefly discuss the channels of mediated and unmediated access that are available to the case study regions. Mediated channels of interest representation are all those that depend upon coordination with and approval of the central government. 
Unmediated channels of interest representation comprise any type of interest representation that does not require coordination with the central government.

\section{Unmediated Channels for Interest Representation}

The most 'institutionalised' channel for subnational authorities is the Committee of Regions $(\mathrm{CoR})$, an advisory organ consisting of representatives of the regional and local level. Its greatest strength is that the Commission is obliged to consult it on a wide range of issues (Art. 265 EC). Since the Treaty of Lisbon, the refocusing of its political strategy on policy areas where consultation is mandatory and on the defence of the principles of subsidiarity and proportionality is seen to have increased its effectiveness (DOMORENOK, 2009, p. 160). The CoR is also seen as providing a setting for coalition-building and the debate of subnational issues at the European level (MÜLLER-GRAFF, 2005, p. 109). However, the CoR only confers collective influence upon its members, and a region therefore needs to engineer a strong majority position before the CoR becomes an effective tool. This is complicated by the diverse membership where strong legislative regions are outnumbered by representatives from local authorities or weak regions (ibid. p. 110).

Regional governments can also target $M E P s$ as a relatively low-cost channel. The most common practice is to contact the MEPs from the region. If a region has access to the chair or rapporteur of a relevant committee, it can influence the direction of debates in the European Parliament. More generally, the MEPs may be able to introduce amendments that reflect the region's concerns. At the lowest level, the region may just get its own MEPs to cast the "right" vote (cf. TATHAM, 2008, pp. 504-6; KNODT et al., 2009, p. 128). However, regions - and especially smaller regions - may only have a small number of MEPs (TATHAM, 2008, p. 504). Those 
MEPs may not even sit in the right committees. In addition, politicians are subject to a variety of pressures, especially rapporteurs, shadow rapporteurs and Committee chairmen, who can receive conflicting position papers from hundreds of actors (Interviews 7, 24).

Thirdly, regions can also try to address the Commission directly, either on the political level or on the level of administrators, for example through participation in consultations and expert meetings, the organization of lobbying events or participation in events organized by other actors. The regional information offices would generally be in charge of facilitating these contacts and events (MOORE, 2006). There is however considerable variation in the importance that different types of regions attach to influencing policies. According to MARKS et al., whether or not a regional office seeks political influence depends on its constitutional strength and its resources (which depend - again - on the constitutional strength of the region) (2002, p. 15). In addition, the format of the offices varies. While the German and Austrian offices are independent from the permanent representations of their country and thus similar to lobbying offices, the Belgian offices are in the same building as the permanent representation, but separate in terms of budgets and staff (SWENDEN, 2009). In the British case, the devolved offices have privileged access to information through the UK permanent representation, but are in return expected to adopt a more moderate stance and to deemphasize conflict with the UK government (BULMER et al., 2006; TATHAM, 2008, p. 507).

Since the 1980s, a variety of more or less specialised networks and associations have been created. Their basis can be very broad, as in the case of the Assembly of European Regions or the Congress of Local and Regional Authorities in Europe, defined by competences, as in the case of the Conference of European Regions with 
Legislative Power (REGLEG), or defined by common features, as in the case of the Conference of Peripheral Maritime Regions. However, these associations only represent the more institutionalised end of regional cooperation. In addition, there are a variety of informal working groups of regions of the same states (such as the thematic working groups of the regional offices of the German Länder) and different states. The question is to what extent these networks generate benefits (KEATING, 1998, p. 178). Undoubtedly, the collective position of several regions holds more weight with the European Commission than the individual position of one single region (TATHAM, 2008, pp. 508-9; KNODT, 2011, pp. 427-428). Yet, in the Scottish context, a leaked draft report from Michael Aron, the then Head of the Scottish Executive European Office, to the Scottish First Minister questioned the effectiveness of both formal partnership agreements with other regions and networks (ARON, 2006, pp. 7, 11-12, 16). Ultimately, the extent to which regions use networks or associations for lobbying purposes remains something of an open question.

\section{Mediated Access}

The participation of regional representatives in the Council of Ministers theoretically provides regions with the most formal and substantial means to influence EU policymaking. However, as article 203 of the Treaty of Maastricht did not specify the precise modalities of this involvement, different national practices evolved (cf. KEATING and HOOGHE, 2006, pp. 274-5). A major limitation to the effectiveness of regional representation in the Council is that whoever sits in the Council has to be able 'to commit the government of that member state' (Art. 203 TEC, 
KOVZIRIDZE, 2002, pp. 131, 136). The position presented consequently has to be the national, not the regional one (HÖGENAUER, 2008).

The Belgian regions have the most extensive representation rights in the Council of Ministers, in line with the Belgian constitutional principle (art. 167) that each part of the state has foreign policy competences in the policy areas that fall under its domestic competences (HOGWOOD et al., 2003, p. 3). When an issue falls under the sole federal responsibility, federal ministers sit in the Council. In case of exclusive regional competences, regional ministers sit in the Council. When predominantly central competences are concerned, a national minister is being assisted by a regional representative and finally, for predominantly regional matters, a regional minister is assisted by a representative of the national level (KERREMANS and BEYERS, 1997). Equality between regions is ensured through a rotation system. In practice, though, ministers of all levels are reluctant to attend in the role of assessors and there are often several regional officials present at all levels of Council meetings to facilitate coordination (KOVZIRIDZE, 2002, p. 149). Separate arrangements apply for fisheries and agriculture.

In the German case the federal government is in a superior position (KOVZIRIDZE, 2002, p. 150). Until 2006, in areas where Länder participated in the domestic legislative process via the Bundesrat, a Länder representative was included in the German delegation if the Länder made a request and if it was possible for the central government to do so (BLArt. 23(6); LC §6(1)). When the exclusive competences of the Länder were concerned, a Länder representative was nominated by the Bundesrat and the Länder could send a minister to the Council and even represent Germany but were not obliged to do so. In practice, the Länder rarely claimed the right to represent Germany in the Council (JEFFERY, 2007). In 2006, the "Federalism I" 
reform limited the policy areas in which Länder ministers can represent Germany in the Council to education, culture and broadcasting. However, the Länder now lead the German delegation in these areas (JEFFERY, 2007; CHARDON and EPPLER, 2009, pp. 29-30).

For Austria, a Länder-nominated representative can participate in the Council if the domestic legislative competences of the Länder are concerned and the national government agrees (Art. 23d Federal Constitution). Thus, the Länder depend on empowerment from the national government even in areas where they are affected (KOVZIRIDZE, 2002, pp. 151-2; BUßJÄGER and DJANANI, 2009, p. 64). In addition, the Liaison Office of the Länder, an administrative structure for the purpose of horizontal and vertical coordination, has one representative in the Austrian Permanent Representation with privileged access to information and Council meetings (PAHL, 2004, p. 113).

The situation in the UK is somewhat similar to the Austrian case, in that the decision on whether or not to include a Scottish minister or expert in the UK delegation rests with the UK lead. Once they are part of the delegation Scottish ministers and officials require the permission of the UK lead before they can take the floor (SWENDEN, 2009).

\section{The European Strategies of the Regions on Bathing Water and Flood Risk}

\section{Management}

Overall, as legislative regions, all of the regions were either present or represented on the European level in some form. At the same time, there were noticeable differences in the extent and form of European level activity between regions including both 
types of channels (mediated/unmediated) and the form of the message (technical/political) (cf. Table 1).

Table 1 here

\section{Extensive Mediated Access to the European Institutions}

The extensive use of mediated access confirms JEFFERY's argument about the importance of domestic channels (2000). All seven regions were individually or collectively represented in Commission working groups and expert meetings at the drafting stage of both Directives, with the exception of the Austrian Länder and the Flood Risk Management Directive.

In the case of the German and Austrian Länder and Scotland, the national expert would take the lead and regional experts could only speak on rare occasions. The German Länder were collectively represented through the representatives of the Bundesrat (Interview 8, 18, 29). Similarly, Länder experts attended the stakeholder meetings for the Flood Risk Management Directive (Interview 27). The Austrian Länder were also represented through their common representative for bathing water, but they were not involved in preparatory meetings on the Flood Risk Management Directive (Interviews 11, 22). Scotland was well represented in the Commission stakeholder meetings and expert groups preparing the proposal for the Bathing Water Directive, as they had commissioned part of the research that informed the UK position (and the final Directive) (Interviews 29, 32, 33). Scotland's participation in the negotiations of the Flood Risk Management Directive was less active, due to a 
late surge in interest. Not all opportunities for participation in the UK delegation were used (Interviews 34, 36).

In line with the principle of "in foro interno, in foro externo", the Belgian regions played a greater role in their national delegation to European level meetings than the other regions. At the drafting stage, the 'pilot', the regional official in charge of coordinating the Belgian position on matters of exclusive regional competence, represented Belgium in the Commission stakeholder meetings (Oral communication 2; Interview 24). In the case of the Flood Risk Management Directive, there were exceptionally two pilots - from Flanders and Wallonia - who would both attend the meetings (Interview 27). In the case of the Bathing Water Directive, both the Flemish pilot and the Walloon expert would participate.

At the decision-making stage, all of the regions were represented on some level in the Council, with the exception of Austria and the Bathing Water Directive. For Germany, the representatives of the Bundesrat participated in meetings of the Council working groups during the negotiations. However, his role was consultative as only the national expert or permanent representative can take the floor (Interview $8,18,17,27)$. In the case of Austria, the common representatives from Styria and Carinthia could represent the Länder in Council working group meetings on flood risk management (Interviews 12, 13). In addition, the Austrian Länder have a representative of their Liaison Office in Brussels, who has access as an observer to Council meetings and meetings of the Committee of Permanent Representatives (COREPER), that prepares the agenda and negotiations in the Council of Ministers. He also attended Council meetings on the two Directives (Interview 26). In the case of the UK, the Scottish expert or somebody from the Scottish Representation would observe Council working group meetings a few times (Interview 32, 33, 34). Scottish 
ministers were also present at several Council meetings where the Flood Risk $\begin{array}{llll}\text { Management } & \text { Directive } & \text { was }\end{array}$ (www.scotland.gov.uk/Topics/Government/International-Relations/Europe/Scotlandin-Brussels/Councils/EUCouncilsArchive). Finally, the regional ministers represented Belgium in the Council at the level of ministers. At the lower levels of the Council, the Permanent Representation would take the lead, but the regional experts and regional attachés to the permanent representation were present as advisors at the level of the working groups, and the regional attachés to the Permanent Representation often attended COREPER as observers (Interviews 20, 21, $23,24,25)$.

Finally, all regions were represented in Commission committees and expert groups at the implementation stage. In general, the opportunities for regional experts to take the floor were perceived to be much greater, so that regions that were directly represented could to some extent promote their approaches. Those regions are of course Scotland, Flanders and Wallonia, but regional experts from Bavaria and Mecklenburg West-Pomerania also attended specific workshops (Interviews 2, 7, 13, 17, 20, 21, 25, 27). Scotland also organised a workshop on catchments and flood management in October 2009 (EUROPEAN COMMISSION, WGF, 2009; Interviews 27,36$)$. Wallonia also organized a workshop on bathing water profiles in Namur during the transposition phase (Interview 21).

Variation between states was thus fairly limited, and mostly concerned the question of individual or collective representation. In the case of the UK and Belgium, which have few (legislative) regions, the regions have direct access to the various European fora. In the case of Germany and Austria, regions were represented as a collective through a common representative (Austria) or representative of the Bundesrat 
(Germany). This does have some impact on the ability of regions to represent their interests. Scottish, Flemish and Walloon officials were sometimes able to voice their own concerns at the level of civil servants, despite the expectation that countries speak with one voice in European institutions. By contrast, the German and Austrian Länder were bound by a collective regional position. At the same time, Scottish officials felt less secure in their representation rights than the officials of the other three member states, because they were aware that their participation rights depended on the goodwill of the UK government (Interview 32).

\section{Limited Unmediated Access to the European Level}

As the overview in Table 1 indicates, the use of unmediated strategies of interest representation was limited. Neither of the Austrian regions made any attempt to gain unmediated access to the European level. The same is true for the German Länder and the Bathing Water Directive and Scotland and the Flood Risk Management Directive. Scotland participated in a seminar in the EP that had been organised by the UK, but otherwise only discussed the Directive with other regions at the margins of the official meetings in Brussels (Interviews 34, 36). In general, the reliance on mediated access can be explained by the absence of conflict between the national and regional goverments in these cases: the cheapest available means to achieve one's goals was to support the national government in its efforts to represent the common interests (cf. HÖGENAUER, 2013).

Where limited unmediated access was established, the EP was the main target. Wallonia had contact with its MEPs for both Directives and informed them of the position and problems of the region (Oral communication 2; Interview 21). Flanders 
only briefed one Dutch MEP on the Flood Risk Management Directive (Interview 20). For the Bathing Water Directive, the Flemish pilot had one discussion with the Dutch rapporteur, whom he visited once with the permanent representative and the Walloon and Flemish attachés. He also used the Commission committees to establish bilateral contact with the Commission desk officers (Interview 25).

There are only two cases of an extensive strategy of unmediated access. Scotland developed a complex strategy on bathing water on the basis of a commissioned report on the quality of bathing water, i.e. scientific expertise and data. The focus was thus very much on technical rather than political arguments and the Scottish position was presented in technical terms throughout the entire negotiation. This is also one of the few cases where networks played a role. In particular, Scottish officials used the European Federation of National Associations of Water and Waste Water Services - EUREAU - to promote shared concerns about the sources of pollution beyond sewage. The involvement in stakeholder networks allowed Scotland to get hold of documents at an early stage and provided it with a platform where it could promote its perspective. Thus, the Scottish expert was invited by EUREAU to a workshop in Barcelona and later by EUREAU and the UK Water industry to speak at a Commission workshop in Vienna. In addition, the Committee of Regions was briefed through the Scottish Representation (Interviews 31, 32).

Contact to key MEPs also played an important part in the Scottish strategy. In particular, with the help of the Scottish Representation, the Scottish experts had contact with Catherine Stihler, who helped them to promote the Scottish perspective by briefing other Scottish and UK MEPs and establishing contact to Martin Schulz, the leader of the then Party of European Socialists. In addition, before the first reading, Catherine Stihler took the Scottish expert to an EP workshop in Strasburg as 
an advisor, where he got the chance to talk to the relevant desk officer of the Commission (Interview 31).

Finally, the Commission attended a Scottish bathing water event in Dundee that Scotland successfully used to promote a signalling system for bad bathing water as best practice (Interviews 31, 32, 33). Overall, while the Scottish strategy involved unmediated access and was quite extensive, it remained largely an insider strategy that relied on scientific arguments about the causes of pollution and possible solutions. The strategy was motivated by initial disagreement with the UK government, but as the disagreement was about technical matters, Scotland generally avoided emphasizing the conflict in public.

The second case of an extensive lobbying strategy is the Bavarian strategy on Flood Risk Management. As in the Scottish case, it was at least in part motived by disagreement with the German government, which reduced the usefulness of the less costly mediated channels. Part of this activity was based on a decision of the German Länder to contact the MEPs to influence the EP's position in the second reading (Interviews 6, 29). As a result, both Bavaria and Mecklenburg-West Pomerania briefed their MEPs on specific amendments (MECKLENBURG-WEST POMERANIA 2007; Interviews 1, 3, 6, 17; VERTRETUNG DES FREISTATES BAYERN BEI DER EU, Europabericht No. 12/2006). In addition, Bavaria, resolutely opposed to the Directive, used administrators and politicians to support a strategy that emphasised both technical aspects (costs, duplication risks) and political aspects (subsidiarity, regional competences) and that could thus be used to raise the question of legitimacy and address a wider public. 
On the administrative level, the Bavaria replied to the Commission consultation in mid-2005 (BAYERISCHES STAATSMINISTERIUM FÜR UMWELT, GESUNDHEIT UND VERBRAUCHERSCHUTZ, 2005). In addition, it took the unusual step of drawing up a cost estimate of the implementation of the Directive and sending this to the Commission. Despite the fact that Bavaria with its 12 million inhabitants is larger than a number of member states and has considerable administrative capacity in EU affairs, the costs of creating such a document were so high that it was the first time ever that Bavaria produced such a document and so far also the last time. In general, this sort of initiative is seen as highly exceptional even amongst large legislative regions as the costs of creating such a document in terms of human resources are regarded as being prohibitively high (Interview 1).

On the political level, three Bavarian Ministers mobilised to defend Bavaria's position. On 20 March 2006, the Minister of the Environment, Health and Consumer Protection, Dr. Werner Schnappauf appeared at an open hearing in the European Parliament in Brussels (SCHNAPPAUF, EP hearing, 20/03/2006). On 21 March 2006, the Bavarian cabinet met, for the first time ever, in the Bavarian office in Brussels to discuss important European topics, including the Flood Risk Management Directive. The Bavarian troika of Minister President Edmund Stoiber, the Minister of Environmental Affairs Dr. Werner Schnappauf and Minister of European Affairs Emilia Müller used this occasion to meet Commission President Barroso to discuss their objections to the Directive and to publicise their opposition at home in a press release which also renewed calls for the federal government to vote against it (BAYERISCHE STAATSKANZLEI, 9/03/2006). Dr. Werner Schnappauf attacked the proposal again in a discussion forum on flood risk management organised on 21 June 2006 in the Bavarian office in Brussels 
(VERTRETUNG DES FREISTAATES BAYERN BEI DER EU, Europabericht No.

12/2006; Interview 3). Finally, Minister President Stoiber used an EU summit on subsidiarity in April 2006 to emphasise once again Bavarian opposition to the Flood Risk Management Directive (BAYERISCHE STAATSKANZLEI, 19/04/2006).

Overall, the use of unmediated access was thus fairly limited when one considers that the seven regions are among the strongest in Europe and had all mobilized extensively domestically. Given the high level of interest and the comparatively great capacity, one could have expected a much higher level of activism in Brussels. Instead, only one region took part in the Commission online consultation. Only two out of fourteen cases involved the development of an extensive lobbying strategy consisting of several actions. Only two regions used networks either to present a common concern or as a platform to present individual concerns. The only channel that was used frequently was the briefing of the regions' MEPs. This tactic was used seven times, i.e. in half of the cases.

\section{A Preference for Expertise}

The fourteen cases show that there is not just a preference for technical expertise on the demand side, but also on the supply side. In thirteen cases, information was nearly exclusively couched in technical language and focused on feasibility, implementation problems and best practice. The Scottish strategy on bathing water illustrates this well. Scotland had a poor record on bathing water quality, so it used scientific studies that it commissioned to demonstrate that some regions may not be able to improve bathing water significantly, as the problems are not just related to sewage. It then used its signaling system to demonstrate that it is possible to prevent 
people from bathing when the quality of water deteriorates due to weather conditions. As a result, the Commission was willing to adapt certain aspects of the Directive to take into account the scientific report and the technological opportunities. Similarly, in addition to the political objections, the Bavarian cost estimate helped to illustrate the point that the Flood Risk Management Directive was too ambitious in its original form.

However, the cases also illustrate potential problems in the supply of expertise. While regions can generally provide some expertise on implementation, a more systematic presentation of the challenges requires a high level of motivation and expertise. Those examples of expertise that stood out and were remembered by the Commission are not just ordinary grass-root expertise. Both the Scottish scientific report and the Bavarian cost estimate required a substantial investment in the production of data. Scotland outsourced the effort and thus had to pay for it, whereas Bavaria produced its own data and found the cost in terms of human resources prohibitive. Thus, even the biggest legislative regions in Europe produce this kind of data only on rare occasions. These investments are very much reserved to high priority dossiers. Scotland struggled with the implementation of the old Bathing Water Directive and feared that the new one would be even stricter, whereas Bavaria anticipated the high costs of a European regulation of Flood Risk Management.

Overtly politicized arguments were only used in one case out of fourteen, and even then only as one element of the strategy. It is mostly in the Bavarian press releases and the speeches by Bavarian Ministers that political concepts such as subsidiarity were evoked. Thus, in 2006, Bavarian Minister-President Stoiber used the Flood Risk Management Directive was then used as an example of a field where the EU tried to legislate, despite being perceived as having no competences in the area. He 
thus opposed the Directive on principle (BAYERISCHE STAATSKANZLEI, 19/04/2006).

\section{How Important is By Passing?}

Overall, the case studies thus allow us to move beyond the somewhat simplistic question in the MLG debate if regions can bypass national governments, and to instead discuss more to what extent they can and do bypass. How common is it for a region to actually use networks, conferences, its regional offices etc. to establish direct access to European actors? What is the nature of those relationships?

\section{The Importance of Mediated Access to the European Level}

In purely quantitative terms, the regions did not establish unmediated access to a European actor in 50 percent of the cases and only established extensive unmediated interaction with European actors in two out of fourteen cases. These cases do, of course, only represent a small fraction of European policy-making. However, we are looking at strong legislative regions, hard law that affects regional competences, policy problems that affect the regions and implementation that involves costs that fall directly on the regions. The cases are thus 'good' cases where one could expect to observe multi-level interactions.

This conclusion that strategies of unmediated access are limited is supported by the views that regional officials expressed about regional engagement in European policy-making. There was almost unanimous agreement on the importance of working through the central government and the national delegation. In fact, it appears that the national route is indeed the "default" route, in that regions always attach great importance to the negotiation of the national position and their 
representation in European policy-making through the national delegation (cf. JEFFERY, 2000). European level strategies, by contrast, are something that is used for special cases, especially when extensive conflict with the national government occurs (cf. HÖGENAUER, 2013; Interviews 6, 7, 10, 11, 12, 18, 22, 24; Written Communication 3).

\section{The Resource Limits of Unmediated Actions at the European Level}

Interviewees from smaller regions in particular were aware of the extent to which long-term investments related to the Brussels offices affect a regions general ability to act. On the one hand, some of the small regions feel that they cannot afford a Brussels office with adequate levels of staff and decide not to have a Brussels office, like Vorarlberg. Regions like Vorarlberg end up with a limited margin of manoeuvre as it is difficult to establish, maintain or expand a Brussels network in the absence of a presence in Brussels (Interview 10).

However, even if smaller Länder opt for their own Brussels office, the challenges are high. Thus, in the Austrian context, BUßJÄGER and DJANANI argue that 'the offices experience further limitations to their 'output' due to limited budgetary resources' (2009, p. 64). ${ }^{\text {iii }}$ The Carinthian office itself has two policy officers (including the Director) who have to do everything from arranging or giving presentations for visitor groups, supervising graduate trainees, running promotional activities, monitoring CoR proceedings, keeping the region at home informed to actual lobbying. As a result, only a handful of issues are followed up, including mainly distributive policy areas and a few topical regulatory policies (e.g. related to energy policy) (Interview 28). 
Even medium-sized offices with seven policy officials in Brussels, like Mecklenburg-West Pomerania, have to be clear on their priorities to be effective, as each member of staff covers issues relating to one and a half or two ministries at home. The Brussels official covering environmental policy also follows agricultural and fishery policy, amongst other things. As Mecklenburg has a long coastline and much agriculture, key initiatives in both of these areas tend to take priority over environmental matters (Interview 30). It is thus only once we move into larger member-state-sized regions that a better ratio of policy areas to staff solves these dilemmas.

At the same time, effective lobbying at the European level requires corresponding investments at home (Interview 3, 30). Policy officers in Brussels lack the specialization to follow up policies on their own. As a result, a higher level of staff in Brussels will only lead to better interest representation if the Land has a corresponding capacity to produce expertise (Interview 30).

The impact of capacity can also be seen in the popularity of MEPs in lobbying strategies. Informing the MEPs from the region only requires the region to send an email or call, and especially in the case of MEPs from the same party as the government, the chances of getting a positive response on at least some points are good. No translations are required, the level of expertise that is required is lower than for the Commission and the ties are closer than to Commission officials.

\section{The Myth of a Subnational-Supranational Alliance}

The case studies also highlight the problematic treatment of the Commission in the literature on multi-level governance. Many authors see it as both a potential ally of 
the subnational level against the central government and as an actor who actively encourages regions to engage in European policy-making (ANDERSON, 1996; ANSELL et al., 1997; TÖMMEL, 1998; BENZ, 1998). However, while the idea of a subnational-supranational alliance presupposes the existence of conflict or power struggle between the regions and the central government, such conflict cannot be taken for granted. In fact, the impression given by recent articles and interviewees alike is that regional-central relations are quite consensual in the overwhelming number of cases. (cf. TATHAM, 2010; Interview 15). Most of the time regions have thus little incentive to escape the clutches of a central state that is quite willing to defend their position.

In particular, policy-specific dynamics play a role in providing a setting for constellations of conflict and alliances. While funding opportunities may facilitate alliances between the regional and European level, the constellations of conflict and alliance are more likely to vary from issue to issue in regulatory policy-making depending on how well a proposal fits the regulatory framework of a region. There is also a high risk of implementation costs and of European initiatives not fitting existing practices in the region. In half the case studies, for instance, there was no conflict between the regions and the central government. Instead, they were joined either in approval of the Commission's intentions (e.g. Austria and the Bathing Water Directive) or in opposition to the policy (e.g. the UK and the Flood Risk Management Directive). European policy-making was thus unlikely to have any impact on the power balance between regional and central governments in these cases. In those cases where conflict did arise, it took various shapes and forms. In the Belgian cases, the regions opted for a common strategy and resolved their disagreements at home. However, even if they had engaged in separate lobbying 
strategies, it would have been a contest of force between regions. The German case on flood risk management is also quite interesting in that respect. While neither the central government nor the regional governments wanted a highly detailed and costly Directive, some non-German interviewees felt that the regions were more opposed than the federal government (Interviews 27, 29).

On the whole, the potential empowering and disempowering effects of Commission initiatives on federal or highly decentralised states in regulatory policy areas are variable and can lead to different constellations of allies. The same is most likely true for non-legislative regions. The only consistent winner in situations of strong domestic conflict is arguably the Commission, as it is presented with a choice of allies. For the same reason, regional and central state actors usually try to avoid open conflict.

\section{Conclusion: The Central State as Gatekeeper?}

On the whole, it appears that for strong legislative regions the "default" approach to regional interest representation in European policy-making is to work through the national delegations, as this is the most cost-effective means of interest representation. Even though in some cases regional representatives mainly acted as observers, the mediated presence at the European level is seen as the extension of regional influence at the national level. As long as a region is satisfied with the national position, it can be a "free rider" and let the central government defend the member state's interest.

While some authors with a focus on structural funds pointed to the opportunities that an alliance between the regions and the Commission presented for regions, 
regulatory policy-making tends to produce very diverse and fluid constellations of interests. Conflict between national governments and legislative regions appears to be relatively rare, whereas conflict with the Commission is much for frequent. The idea of the alliance against the central state is something of a myth and it could be argued that a central-regional alliance is much more common (TATHAM, 2010).

Genuine unmediated interest representation is less common, and when it occurs it is limited to sporadic acts. Most commonly, legislative regions will contact their MEPs to influence the position of the Parliament. The European Commission is comparatively rarely subject to unmediated lobbying, even though it is the target of regional activity through official channels. Neither the Committee of the Regions nor networks played a major role in interest representation. Overall, unmediated regional activities at the European level are very much supplementary in nature.

Part of the reasons for the limited unmediated activity are the investments required. Especially smaller regions struggle with the costs of unmediated interest representation, of having a large Brussels office and sustaining lobbying strategies over a longer period of time. But even larger offices do not have the capacity to actively engage in all negotiations. Instead, regions generally focus their resources on a limited number of high priorities.

As a result, the central state is still very much at the heart of every-day representation in European policy-making and in many cases regional-supranational relations are mediated. However, this does not mean that the central government is a gatekeeper who controls the interactions between the subnational and the supranational level. First of all, in the case of the strongest regions, the Belgian regions, the role of the government in domestic coordination has largely receded to that of a mediator in 
areas of exclusive regional competences (BURSENS and GEERAERTS, 2006; HÖGENAUER, 2013). Secondly, to some extent central governments mediate because their regions allow them to mediate. While it is true that this regional choice is to some extent based on resource-constraints and that the regions would not be able to systematically challenge the authority of the central state on a large number of policies simultaneously, they can and do challenge its authority on some policies.

\section{Acknowledgements}

This article is based on research conducted during my $\mathrm{PhD}$ at the University of Edinburgh and contains unpublished material from my $\mathrm{PhD}$ thesis. Special thanks go to the numerous colleagues who have provided feedback on my research, in particular Charlie Jeffery, Wilfried Swenden, Nicola McEwen and the Territorial Politics Reserch Group at the University of Edinburgh.

\section{Bibliography}

ANDERSON J. (1996) Germany and the Structural Funds: Unification Leads to Bifurcation. In:

L. HOOGHE ed. (1996) Cohesion Policy and European Integration: Building Multi-level Governance. Clarendon Press, Oxford.

ANSELL C., PARSONS C., and DARDEN K. (1997) Dual Networks in European Regional Development Policy. Journal of Common Market Studies 35(3) 347-75.

ARON M. (2006) EU Business: Reviews of Engagement with Europe and of EU Office. Report commissioned by the Scottish Executive.

BACHE I. (2008) Europeanization and Multi-level Governance: Cohesion Policy in the European Union and Britain. Rowman and Littlefield, Lanham/New York. 
BAYERISCHE STAATSKANZLEI (2006) EU-Hochwasser-Richtlinie: Bayerns Europaministerin

Emilia Müller fordert Bundesregierung auf, im EU-Rat mit Nein zu stimmen. Press

Release, Pressearchiv, 9/03/2006, accessed 20/10/2008.

BAYERISCHE STAATSKANZLEI (2006) Stoiber fordert beim EU-Subsidiaritätsgipfel eine stärkere Beteiligung der nationalen Parliamente an der EU-Rechtssetzung. Press Release, 19/04/2006,

www.stkarchiv.bayern.de/imperia/md/content/stk/pressemitteilungen/stk/2006/06041 9_subsidiaritaetsgipfel.pdf, accessed 16/04/2006.

\section{BAYERISCHES STAATSMINISTERIUM FÜR UMWELT, GESUNDHEIT UND}

VERBRAUCHERSCHUTZ (2005) Comments by Bayerisches Staatsministerium für Umwelt, Gesundheit und Verbraucherschutz.

ec.europa.eu/environment/water/flood_risk/consult.htm, accessed 16/04/2010.

BENZ A. (1998) German Regions in the European Union: from joint policy-making to multilevel governance. In: P. LE GALES and C. LEQUESNE eds. Regions in Europe. Routledge, London, pp. 111-29.

BEYERS J. (2002) Gaining and Seeking Access: The European Adaptation of Domestic Interest Associations. European Journal of Political Research 41(5) 585-612.

BEYERS J. (2004) Voice and Access. Political Practices of European Interest Associations. European Union Politics 5(2) 211-40.

BEYERS J. (2008) Policy Issues, Organisational Format and the Political Strategies of Interest Organisations. West European Politics 31(6) 1188-211.

BEYERS J. and KERREMANS B. (2012) Domestic Embeddedness and the Dynamics of Multilevel Venue Shopping in Four EU Member States. Governance 25(2) 263-90. BOUWEN P. (2004) Exchanging Access Goods for Access: A Comparative Study of Business Lobbying in the European Union Institutions. European Journal of Political Research 43(3) 337-69. 
BULMER S., BURCH M., HOGWOOD P., SCOTT A. (2006) UK Devolution and the European Union: A Tale of Co-operative Asymmetry. Publius, The Journal of Federalism 36(1) 7594.

BURSENS P. and GEERAERTS K. (2006) EU Environmental Policy-Making in Belgium: Who Keeps the Gate?. Journal of European Integration 28(2) 159-79.

BUßJÄGER P. and DJANANI A. (2009) Europapolitik und Europafähigkeit der Länder in Österreich. In: K.-H. LAMBERTZand M. GROßE HÜTTMANN eds. Europapolitik und Europafähigkeit von Regionen. Nomos, Baden-Baden, pp. 58-70.

CHALMERS A. (2013) Trading Information for Access: Informational Lobbying Strategies and Interest Group Access to the European Union. Journal of European Public Policy 20(1) $39-58$.

CHARDON M. and EPPLER A. (2009) Mehr europapolitische Handlungsspielräume für die deutschen Länder? Die Auswirkungen der Föderalismusreform I und des Vertrags von Lissabon. In: K.-H. LAMBERTZ and M. GROßE HÜTTMANN eds. Europapolitik und Europafähigkeit von Regionen. Baden-Baden, Nomos, pp. 25-41.

DOMORENOK E. (2009) The Committee of the Regions: In Search of Identity. Regional and Federal Studies 19(1) 143-63.

DONAS T. and BEYERS J. (2012) How Regions Assemble in Brussels: The Organizational Form of Territorial Representation in the European Union. Publius: The Journal of Federalism 43(4) 527-50.

DÜR A. and MATEO G. (2013) Gaining Access or Going Public? Interest Group Strategies in Five European Countries. European Journal of Political Research 52(5) 660-86. EUROPEAN COMMISSION, Working Group F, Catchment Flood Risk Management Workshop, 15/16 October 2009, Stirling, www.scotland.gov.uk/Resource/Doc/1057/0097183.pdf, accessed 26/04/2010. 
GREENWOOD J. (2011) Actors of the Common Interest? The Brussels Offices of the Regions, Journal of European Integration. 33(4) 437-52.

GREER S., MASSARD DA FONSECA E., ADOLPH C. (2008) Mobilizing Bias in Europe: Lobbies, Democracy and EU Health Policy-Making. European Union Politics 9(3) 403-33.

HALL P.A. and TAYLOR R.C.R. (1996) Political Science and the Three New Institutionalisms. Political Studies 44(5) 936-57.

HERITIER A. (1996) The Accommodation of Diversity in European policy-making and Its Outcomes: Regulatory Policy as a Patchwork. Journal of European Public Policy 3(2) 14976.

HÖGENAUER A.L. (2008) The Impact of the Lisbon Reform Treaty on Regional Engagement in EU Policy-Making - Continuity or Change?. European Journal of Law Reform X(4) 53555.

HÖGENAUER A.L. (2013) All by Themselves? Legislative Regions and the Use of Unmediated Access to the European Level. European Political Science Review. DOI: http://dx.doi.org/10.1017/\$1755773913000180, 11 November 2013. HOGWOOD P., GOMEZ R., BULMER S., BURCH M., CARTER C., SCOTT A. (2003) Regional actors and European policy making: lessons for the UK? Manchester Papers in Politics: Devolution and European Policy Series 8/2003, www.socialsciences.manchester.ac.uk/disciplines/politics/publications/workingpapers/d ocuments/manchester working papers/MPP082003.pdf.

HOOGHE L. and MARKS G. (2001) Multi-Level Governance and European Integration. Rowman \& Littlefield Publishers, Oxford.

JEFFERY C. (2000) Subnational Mobilization and European Integration: Does it Make any Difference? Journal of Common Market Studies 38(1) 1-23. 
JEFFERY C. (2007) Towards a New Understanding of Multi-Level Governance in Germany? The Federalism Reform Debate and European Integration. Politische Vierteljahresschrift 48(1) $17-27$.

KEATING M. (1998) The New Regionalism in Western Europe. Territorial Restructuring and Political Change. Edward Elgar, Cheltenham.

KEATING M. and HOOGHE L. (2006) Bypassing the Nation-state? Regions and the EU Policy Process. In: J.J. RICHARDSON ed. European Union: Power and Policy-Making. (2nd edn). Routledge, London.

KERREMANS B. and BEYERS J. (1997) The Belgian Sub-National Entities in the European Union: Second or Third Level Players? In: C. JEFFERY ed. The Regional Dimension of the European Union - Towards a Third Level in Europe? Frank Cass, London.

KNODT M. (2011) Strategies of Territorial and Functional Interests: Towards a Model of European Interest Intermediation? Journal of European Integration 33(4) 419-36.

KNODT M., GREENWOOD J. and QUITTKAT C. (2011) Territorial and Functional Interest Representation in EU Governance. Journal of European Integration 33(4) 349-68.

KNODT M., GROßE HÜTTMANN M. and KOTZIAN P. (2009) Die Brüsseler Informationsbüros der deutschen Länder: Aktive Mitspieler im Mehrebenensystem der EU. In: K.-H. LAMBERTZ, M. GROßE HÜTTMANN eds, Europapolitik und Europafähigkeit von Regionen. Nomos, Baden-Baden, pp. 123-35.

KOVZIRIDZE T. (2002) Europeanization of Federal Institutional Relationships: Hierarchical and Interdependent Institutional Relationship Structures in Belgium, Germany and Austria. Regional and Federal Studies 12(3) 128-55.

MARKS G. (1993) Structural Policy and Multilevel Governance in the EU. In: A. CAFRUNY and G. ROSENTHAL eds. The State of the European Community. Lynne Rienner, New York, pp. $164-92$. 
MARKS G., HAESLY R. and MBAYE H.A.D. (2002) What Do Subnational Offices Think They Are Doing in Brussels? Regional and Federal Studies 12(3) 1-23.

MARKS G., HOOGHE L. and BLANK K. (1996) European Integration from the 1980s: State Centric v. Multi-level Governance. Journal of Common Market Studies 34(3) 341-78.

MECKLENBURG-WEST POMERANIA (2007), internal document, Richtlinie des Europäischen Parlaments und des Rates über die Bewertung und das Management von Hochwasserrisiken - Entwurf einer Empfehlung für die Zweite Lesung, 6/02/2007.

MOORE C. (2006) 'Schloss Neuwahnstein'? Why the Länder Continue to Strengthen Their Representations in Brussels. German Politics 15(2) 192-205.

MOORE C. (2008) A Europe of the Regions vs. the Regions in Europe: Reflections on Regional Engagement in Brussels. Regional and Federal Studies 18(5) 517-35.

MÜLLER-GRAFF P.C. (2005) The German Länder: Involvement in EC/EU Law and PolicyMaking. In: S. WEATHERILL and U. BERNITZ eds. The role of Regions and Sub-National Actors in Europe. Hart Publishing, Oxford.

PAHL M.-O. (2004). Regionen mit Gesetzgebungskompetenz in der Europäischen Union. Nomos, Baden-Baden.

PETERS B.G. (2000) Institutional Theory: Problems and Prospects. Reihe Politikwissenschaft 69, Institut für Höhere Studien, Vienna.

POLONI-STAUDINGER L. (2008) The Domestic Opportunity Structure and Supranational Activity: An Explanation of Environmental Group Activity at the European Union Level. European Union Politics 8(4) 531-58.

PRINCEN S. (2011) Agenda-setting Strategies in EU Policy-Processes. Journal of European Public Policy 18(7) 927-43.

QUITTKAT C. and KOTZIAN P. (2011) Lobbying via Consultation - Territorial and Functional Interests in the Commission's Consultation Regime. Journal of European Integration 33(4) 401-18. 
SCHNAPPAUF W., Bavarian Minister of the Environment, Health and Consumer Protection. Hochwasser: Reaktionen und Planung auf regionaler Ebene. Joint Public Hearing Natural Disasters: How Should Europe Respond?, European Parliament, Brussels, 20/03/2006, www.europarl.europa.eu/comparl/envi/hearings/natural_disasters/default_en.htm, accessed 16/04/2010.

SWENDEN W. (2009) Schottland in Europa: Mit oder ohne Vereinigtes Königreich? In: K.-H. LAMBERTZ and M. GROßE HÜTTMANN eds., Europapolitik und Europafähigkeit von Regionen. Nomos, Baden-Baden, pp.101-22.

TATHAM M. (2008) Going Solo: Direct Regional Representation in the European Union. Regional and Federal Studies 18(5) 493-515.

TATHAM M. (2010) With or Without You? Revisiting Territorial State-Bypassing in EU Interest Representation. Journal of European Public Policy 17(1) 76-99.

TÖMMEL I. (1998) Transformation of Governance: The European Commission's Strategy for Creating a 'Europe of the Regions'. Regional and Federal Studies 8(2) 52-81.

VERTRETUNG DES FREISTAATES BAYERN BEI DER EU, Europabericht No. 12/2006

(23/06/2006), www.bayern.de/Europaberichte-.746/index.htm, accessed 16/04/2010.

WOLL C. (2006) Lobbying in the European Union: From suigeneris to a comparative perspective. Journal of European Public Policy 13(3) 456-69.

www.scotland.gov.uk/Topics/Government/International-Relations/Europe/Scotland-inBrussels/Councils/EUCouncilsArchive. Attendance records of Scottish ministers in Council of Ministers.

\section{Interviews}

Interview 1: official (1), Bavarian Ministry of the Environment and Health, Munich, 4/03/2009. 
Interview 2: official (2), Bavarian Ministry of the Environment and Health, Munich, 4/03/2009.

Interview 3: official, Bavarian Ministry of the Environment and Health and former member of the Bavarian Representation in Brussels, Munich, 4/03/2009.

Interview 6: official, Ministry of Agriculture, Environment and Consumer Protection, Schwerin, 16/03/2009.

Interview 7: official, Ministry of Social Affairs of Mecklenburg-West Pomerania, Schwerin, 18/03/2009.

Interview 8: official (1), Federal Ministry of the Environment, Bonn, 20/03/2009. Interview 10: official, Amt der Vorarlberger Landesregierung, Abteilung für Europaangelegenheiten und Außenbeziehungen, telephone, 26/03/2009. Interview 11: official, Amt der Kärntener Landesregierung, Abteilung 15, Klagenfurt, 30/03/2009.

Interview 12: official, Amt der Kärntener Landesregierung, Abteilung 18, Klagenfurt, $30 / 03 / 2009$.

Interview 13: official (1), Federal Ministry of the Environment, Vienna, 1/04/2009. Interview 14: official (2), Federal Ministry of the Environment, Vienna, 1/04/2009. Interview 15: official, Liaison Office of the Austrian Länder, Vienna, 2/04/2009. Interview 17: representative of the Bundesrat for flood risk management, telephone, 7/04/2009.

Interview 18: representative of the Bundesrat for bathing water, telephone, 24/04/2009. Interview 20: official, VMM, Brussels, 18/05/2009. Interview 21: official, DGARNE, Namur, 20/05/2009. Interview 23: official, Belgian Permanent Representation, Brussels, 27/05/2009. Interview 24: official, Flemish Delegation to the Belgian Permanent Representation, Brussels, 5/06/2009. 
Interview 25: official, VMM, Gent, 8/06/2009.

Interview 26: representative of the Liaison Office of the Austrian Länder in Brussels,

Brussels., 8/06/2009.

Interview 27: European Commission official, DG Environment, Brussels, 9/06/2009.

Interview 28: Director of the Carinthian Office in Brussels, Brussels, 9/06/2009.

Interview 29: European Commission official, DG Environment, Brussels, 11/06/2009.

Interview 30: official, Brussels office of Mecklenburg-West Pomerania, Brussels,

$12 / 06 / 2009$.

Interview 31: former official of the Water, Air, Soils and Flooding Division of the Scottish

Government, 24/06/2009.

Interview 32: former official of the Water, Air, Soils and Flooding Division of the Scottish

Government, Edinburgh, 1/07/2009.

Interview 33: former official of DEFRA, telephone, 7/7/2009.

Interview 34: official, DEFRA, telephone, 17/07/2009.

Interview 36: official, Water, Air, Soils and Flooding Division of the Scottish Government, Edinburgh, 25/09/2009.

\section{Oral and Written Communications ${ }^{i v}$}

Oral communication 2: official, Walloon delegation to the Belgian Permanent

Representation, telephone, 3/06/2009.

Written communication 3: official, SEPA, 21/07/2009.

\footnotetext{
'In EU policy-making, the European Commission has the sole right of initiative in most policy-areas. The Council of Ministers (representing the member state governments) and the directly elected
} 
European Parliament are co-legislators in most instances of legislative policy-making, including the case studies in this article. Once legislation has been adopted, the Commission coordinates and supervises its transposition in to national law and its implementation. The Committee of the Regions, which is mentioned later in the article, is an official advisory organ of the European Union composed of representatives of the regional and local levels of the member states. It has to be consulted by the Parliament and the Council on a wide range of policies.

ii Directive 2006/7/EC of the European Parliament and of the Council of 15 February 2006 concerning the management of bathing water quality and repealing Directive 76/160/EEC, OJ L 064 , 4/03/2006, pp. 37-51. Directive 2007/60/EC of the European Parliament and of the Council of 23 October 2007 on the assessment and management of flood risks, OJ L 288, 6/11/2007, pp. 27-34.

iii Translated by the author.

iv 'Oral communication' refers to shorter conversations with officials, usually on the phone. 